\title{
Learning Facilities that Can Develop Science Process Skills in Indonesia: Review of Experimental Studies
}

\author{
Muhammad Syazali, Muhammad Erfan, Baiq Niswatul Khair* \\ Elementary School Teacher Study Program, Faculty of Teacher Training and \\ Education, Universitas Mataram \\ *Corresponding Author. Email: baiqniswatul_fkip@unram.ac.id
}

\begin{abstract}
Aims of this study are to analyze: (1) types of learning facilities, (2) variants of each type of learning facilities, and (3) recommendations for implementation of variants of types of learning facilities that are empirically proven to be effective in developing the science process skills of students in Indonesia. This research is a literature review study. The data sources are articles in journals and proceedings published from 2016 to 20120. The articles that have been collected are then analyzed using the thematic method. Learning facilities consist of 7 types, namely strategies, approaches, models, methods, media, and learning aids. In total there are 106 variants with details of 7 variants of the type of strategy, 7 variants of the type of approach, 34 variants of the type of model, 11 variants of the type of method, 28 variants of the type of media, 5 variants of the type of teaching aid, and 15 variants of the type of learning device. From these various variants, there are 7 variants that are recommended to be used in facilitating students and students in developing their SPS. The variants are guided inquiry learning models, inquiry, PBL, PjBL and learning cycles, as well as learning media variants of modules and worksheets. This review is useful as a reference for teachers and lecturers because it provides various choices of learning facilities that can be applied to improve science process skills. The many choices help them to match the characteristics of the learners to be facilitated, their ability to implement, and the availability of infrastructure.
\end{abstract}

\section{Article History}

Received: 04-08-2021

Revised: 18-10-2021

Accepted: 20-11-2021

Published: 11-12-2021

Key Words: Learning Facility, Science Process Skills, Learning Model, Instructional Media.

How to Cite: Syazali, M., Erfan, M., \& Khair, B. (2021). Learning Facilities that Can Develop Science Process Skills in Indonesia : Review of Experimental Studies. Jurnal Kependidikan: Jurnal Hasil Penelitian dan Kajian Kepustakaan di Bidang Pendidikan, Pengajaran dan Pembelajaran, 7(4), 910-923. doi:https://doi.org/10.33394/jk.v7i4.4414

https://doi.org/10.33394/jk.v7i4.4414

This is an open-access article under the CC-BY-SA License.

\section{Introduction}

Science process skills are competencies that are owned and used by scientists to conduct scientific investigations. The results of these investigations are facts, theoretical concepts, principles and laws that look into aspects of scientific products. Based on this, it can be said that science process skills are the basic competencies needed to master science products (Prayitno et al., 2015). Science process skills are classified into 2 tipes; basic and integrated science process skills. Martin calls integrated science process skills as superior skills (Can et al., 2017). Science process skills consist of indicators that show that these skills can help students provide the best solutions to the problems they encounter in everyday life. Therefore, education equips students with these competencies through the science learning process.

Judging from the tendency, science education in Indonesia is dominated by mastery of science products. This has an impact on mastering science only on facts, concepts, theories, principles and laws without skills related to how to get them. Furthermore, students have a relatively low ability to solve problems in everyday life. The low scientific literacy of students in Indonesia (Schleicher, 2019), one of which is caused by their low science process 
skills. This statement refers to the results of research on the science process skills of students in Indonesia (Prahani et al., 2021; Rahayu \& Anggraeni, 2017; Rahman et al., 2017). Similarly, students' science process skills (Deta et al., 2020; Julianto et al., 2018; Sari \& Zulfadewina, 2018). This is exacerbated by the obstacles to implementing online learning or distance learning due to the Covid-19 pandemic (Giatman et al., 2020; Hidayati \& Saputra, 2020; Mirawati et al., 2020).

There are various learning facilities that are empirically proven to be able to improve and develop the science process skills of students in Indonesia (Badria et al., 2021; Munzil \& Rochmawati, 2021; Nurulwati et al., 2021). However, this information is scattered in various research articles. So it takes a literature review research to collect the various types of learning facilities. This study reviews the various scattered learning facilities as needed. Teachers and lecturers or prospective teachers and lecturers can use it as a reference to choose suitable facilities given to students or students. The number of choices is also a solution to the high heterogeneity of students and students. Heterogeneity itself causes learning facilities to be effective against certain groups of students, but not necessarily effective against other groups of students. For prospective teachers and lecturers, this paper can provide them with pedagogic competencies as preparation to provide the best learning facilities to students or students when they become facilitators.

\section{Research Method}

This study is a literature review research that uses articles as a data source. Articles are collected through a search on Google Scholar using the keywords "science process skills" and "science process skills". The articles that are used as references are articles from research conducted in Indonesia and published between 2011 and 2020. The articles are related to learning facilities that are influential and/or can improve/develop students' science process skills. Thus the source of the data in question is obtained from experimental research - quasiexperimental and pre-experimental and classroom action research. The process succeeded in collecting as many as 351 documents. The largest number of publications occurred in 2017 with 112 documents. In second place are publications in 2016 with a total of 89 documents, then publications in 2018 with 78 documents, in 2019 with 44 documents, and in 2020 at least with a total of 28 documents (Figure 1). These documents were then analyzed using the thematic method referring to Amalia \& Kurniawati (2021). The aim is to identify the data in detail.

When viewed from the year of publication at each level of education, the number of publications increased in number until 2017, then decreased continuously until 2020. This trend was observed at all levels of education except for basic education (Figure 2a). At the basic education level, a downward trend in the number of publications has occurred since after 2016. However, the gradient of decline is not as large as in the secondary and higher education levels. Based on education level, the largest proportion of publications is at the high school level. The number of documents during the 2016 - 2020 range was 173 documents, with a percentage of $49.29 \%$. The second largest proportion is publications at the junior secondary level with 93 documents $(26.50 \%)$. The next sequence is publications at the basic education level and higher education (Figure 2b). 


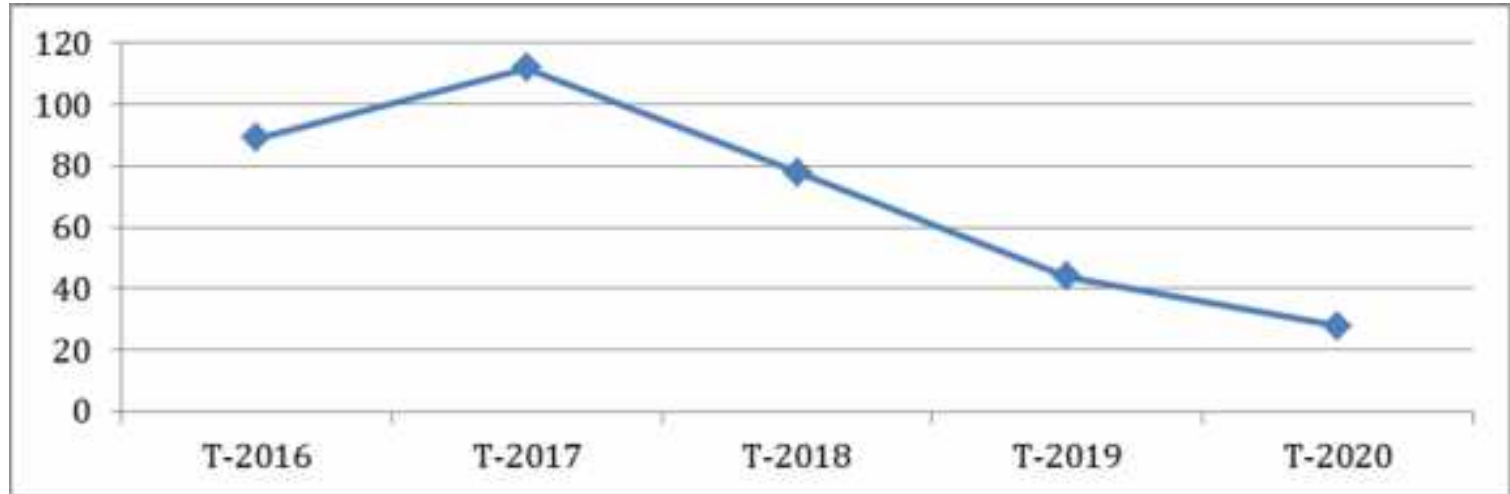

Figure 1. Distribution of the Number of Published Articles from 2016 - 2020

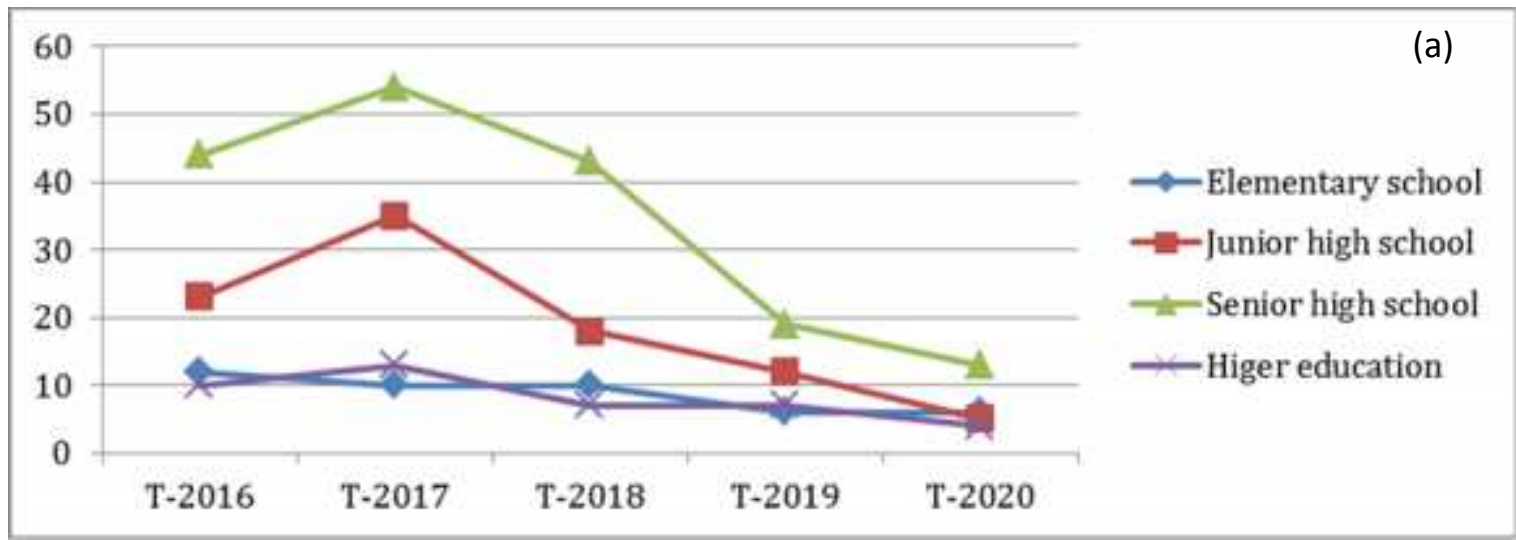

Figure 2. Proportion of Publications at Various Levels of Education

$\left.\begin{array}{r}200 \\ 100 \\ 160 \\ 140 \\ 120 \\ 100 \\ 80 \\ 60 \\ 40 \\ 20 \\ 0\end{array}\right]$
Education Level

\section{Results and Discussion}

\section{Types of Learning Facilities}

Learning facilities that can improve the SPS of students and students in Indonesia are classified into 7 groups, namely tools, strategies, approaches, models, methods, media, and teaching aids. At the implementation level, the proportion of the use of the learning model is the largest among the groups of facilities. The percentage reached $51.28 \%$. The second proportion is the use of learning media by $25.13 \%$, and the smallest proportion is the use of learning aids by $1.54 \%$ (Figure 4). This shows that to develop SPS for students, researchers in 
Indonesia are more confident in the use of learning models compared to other learning facilities. This fact also shows that the learning model is the most favorite learning facility.

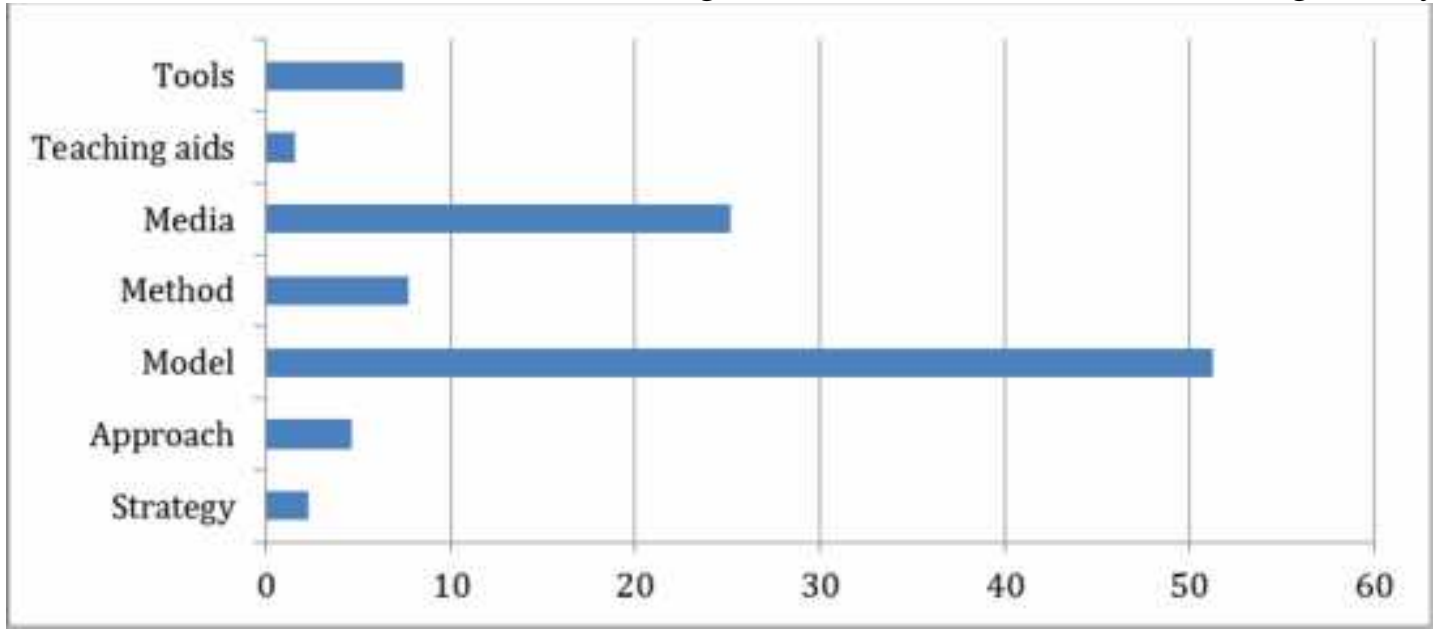

Figure 4. Proportion of Use of Learning Facilities

Based on the level of education, not all types of learning facilities that are implemented to develop SPS students are effective at the basic education level. Of the seven variations, there is one learning facility that is not used, namely teaching aids. This means that the use of teaching aids as learning facilities in basic education has not been proven effective in developing students' SPS. However, this does not prove that the props are completely ineffective. Generally, students who receive education at the elementary level feel a more meaningful learning experience if it is facilitated with concrete objects compared to abstract objects. Referring to Piaget (1936), their cognitive development is still in the concrete operational phase or the initial phase at the formal operational level (Huang, 2021). So that teaching aids have the potential to develop students' SPS at the basic level through providing learning experiences that are in accordance with their level of thinking.

Empirically, learning facilities that can provide meaningful learning experiences according to the level of development of students at the basic education level include tools, media, methods, models, approaches and learning strategies. The model is the type of learning facility that is most widely used to develop students' SPS. The total articles are 31 documents with a proportion of 58.49\%. The proportion of other learning facilities ranges from $3.77 \%$ to $15.09 \%$. More complete information is presented in Figure 5a. This proves that the learning model is the most suitable type of facility to be implemented in order to develop PPP in basic education.

At the junior high school level (equivalent), the learning facility that is most often used to develop students' KPS is the learning model (50.48\%). The total articles reached 53 documents. Learning media is in second place with a proportion of $21.90 \%$, and the third most used is learning tools with a proportion of $13.33 \%$. As for other learning facilities strategies, approaches, methods and teaching aids the proportion is below 10\%. More detailed information is available in Figure 5b. At the high school level (equivalent), the most widely used learning facility is the learning model. The proportion of implementation is $56.61 \%$. Although this proportion is smaller than the proportion of implementation in primary and junior secondary education, the total number is larger than the two levels of education. The total number of articles that use learning models to develop students' KPS is 107 documents. In second place is the implementation of learning media with the number of articles as many as 42 documents and the proportion of $22.22 \%$. Other types of equipment have proportions ranging from $1.06 \%$ to $8.47 \%$ (Figure $5 \mathrm{c}$ ). 
Based on the results of the analysis, the most widely used type of learning facilities to develop students' science process skills in Indonesia is learning media. The number of articles reporting the implementation of this learning facility is 24 documents, with a proportion of $58.14 \%$. This is different from the findings in primary and secondary education, where the most dominant learning facility used is the learning model. Nevertheless, the learning model remains one of the favorites because the number of implementations is second. The number of articles reached 10 documents with a proportion of $20.93 \%$. Other types of learning facilities have proportions ranging from $4.65 \%$ to $11.63 \%$ (Figure 5d). At the higher education level, there are two types of learning facilities that are not used to develop student KPS, namely learning tools and teaching aids.

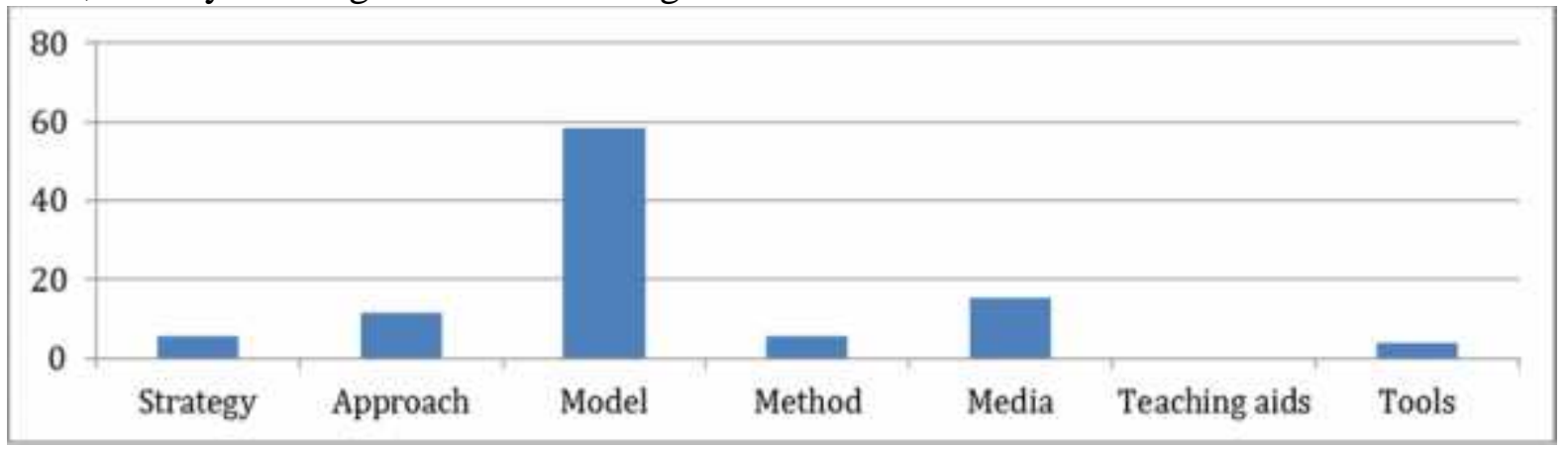

Figure 5a. Proportion of Implementation of Types of Learning Facilities in Elementary School (ES)

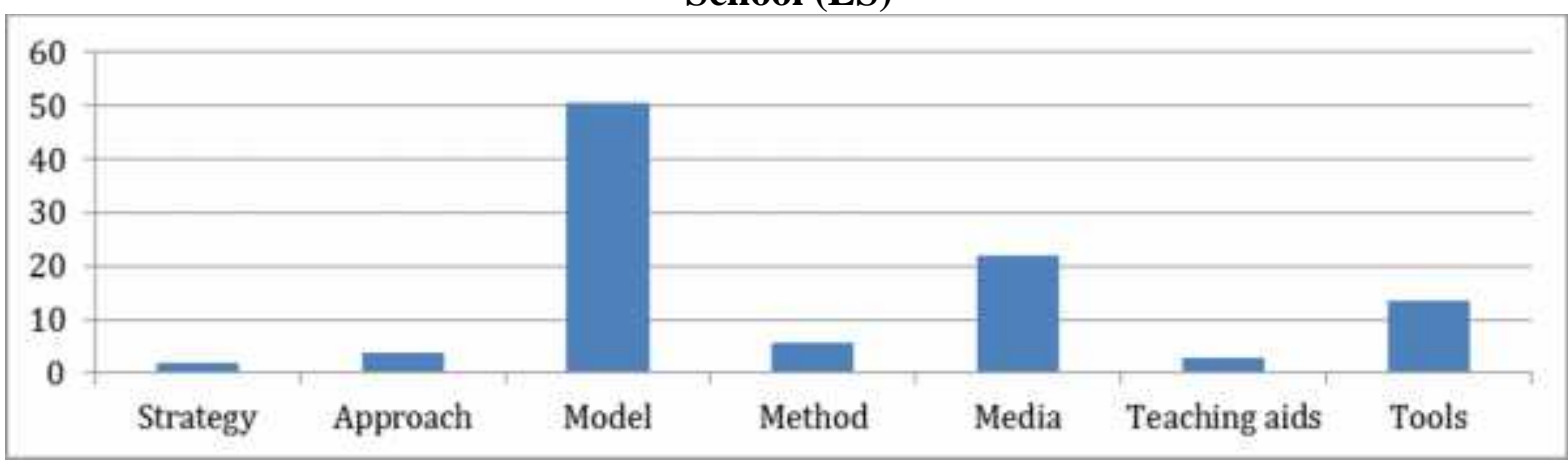

Figure 5b. Proportion of Implementation of Types of Learning Facilities in Junior High School (JHS)

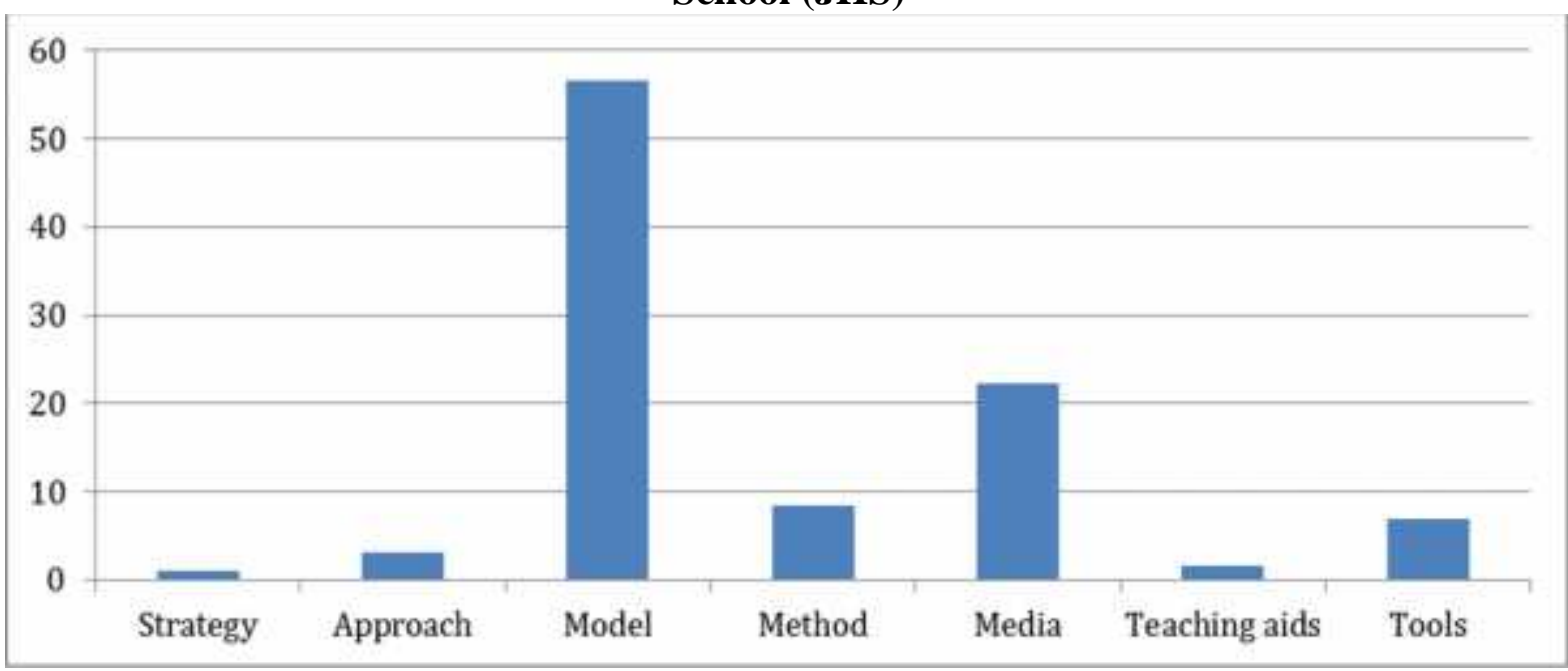

Figure 5c. Proportion of Implementation of Types of Learning Facilities in Senior High School (SHS)

Jurnal Kependidikan Vol. 7, No. 4 (December 2021) 


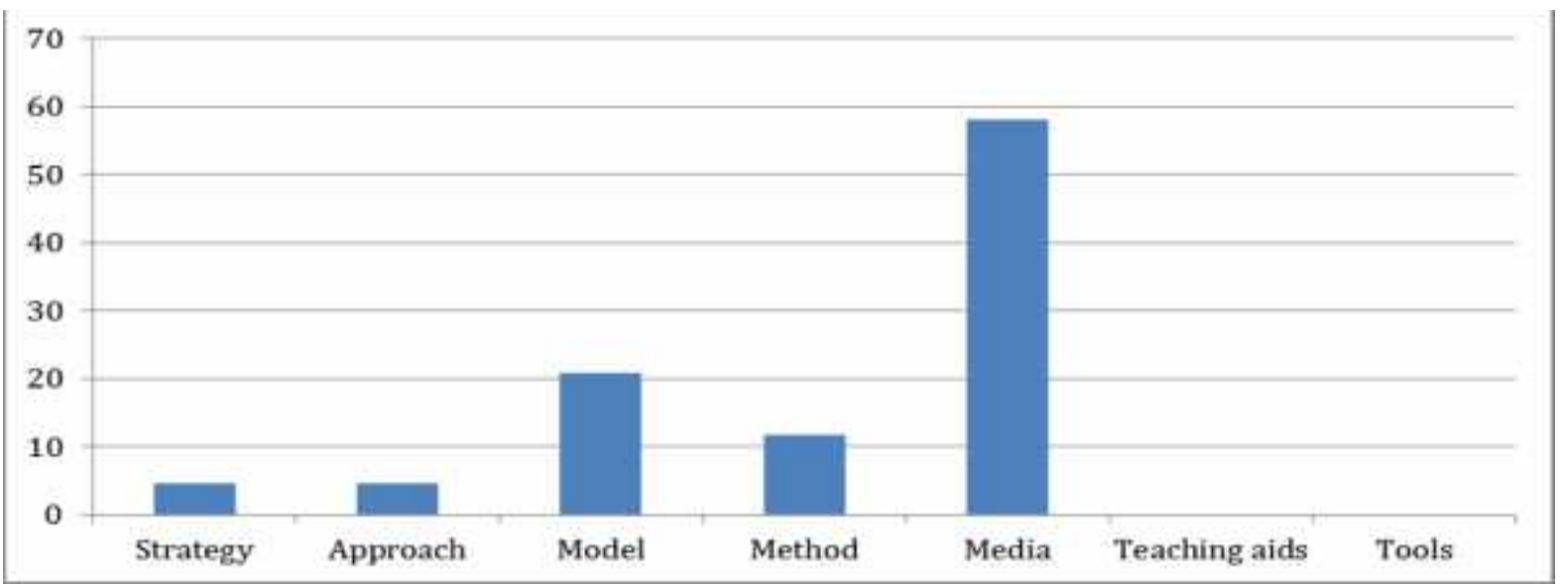

Figure 5d. Proportion of Implementation of Types of Learning Facilities in Higer

\section{Variants of Learning Facilities}

Education (HE)

Each type of learning facility that has been proven to be able to develop the SPS of students in Indonesia consists of various variants. In total there are 113 variants of 7 types of learning facilities. The frequency of implementation in facilitating the learning process varies. There is a variant whose frequency is only one, up to a variant whose frequency reaches 62. This most frequently used variant proves that the variant is the favourite, and is proven empirically through research. More detailed information is presented in the following review.

\section{1) Learning strategies}

This type of learning facility has seven variants that are empirically proven to be able to develop student and student SPS. The seven variants are (7) inquiry, (2) Ethno-STEM, (3) science extracurricular, (4) Student Generative Representation (SGRs), (5) Relating, Experiencing, Applying, Cooperating, Transfering (REACT), (6 ) scaffolding, and (7) Practical-Based Jigsaw. The frequency and proportion of implementation are presented in Table 1.

Table 1. Variants of learning strategies that are proven to be able to develop SPS

\begin{tabular}{|c|c|c|c|c|c|c|c|}
\hline \multirow{2}{*}{ No } & \multirow{2}{*}{ Varians } & \multicolumn{4}{|c|}{ Frequency } & & \multirow{2}{*}{$\begin{array}{l}\text { Proportion } \\
(\%)\end{array}$} \\
\hline & & ES & JHS & SHS & $\mathrm{HE}$ & & \\
\hline 1 & Inquiry & 1 & 0 & 0 & 1 & 2 & 22.22 \\
\hline 2 & Ethno-STEM & 1 & 0 & 0 & 0 & 1 & 11.11 \\
\hline 3 & Science extracurricular & 1 & 0 & 0 & 0 & 1 & 11.11 \\
\hline 4 & SGRs & 0 & 1 & 0 & 0 & 1 & 11.11 \\
\hline 5 & REACT & 0 & 1 & 1 & 0 & 2 & 22.22 \\
\hline 6 & Scafolding & 0 & 0 & 1 & 0 & 1 & 11.11 \\
\hline 7 & Practical-based jigsaw & 0 & 0 & 0 & 1 & 1 & 11.11 \\
\hline
\end{tabular}

Table 1 contains information that the inquiry learning strategy has been proven to be effective in developing students' SPS at the elementary and higher education levels. Two strategies - ethno-STEM and extracurricular science - have so far only been proven in students in primary education. Other strategies such as SGRs have proven effective in junior secondary education, REACT strategies are effective in secondary education, scaffolding strategies in senior secondary education, and practical-based jigsaw strategies have proven effective in college students. In its implementation, the SGRs learning strategy is combined with a guided inquiry learning model. 


\section{2) Learning approach}

The learning approach that we have found to be effective in developing PPP consists of seven variants. The variants are (1) inquiry, (2) scientific, (3) contextual, (4) guided inquiry, (5) interactive demonstration, (6) brain based learning, and (7) somatic, auditory, visual intellectual, repetition (SAVIR). As in the variants of learning strategies, in the learning approach, several variants were also found that were proven at more than one level of education, while other variants were only proven at one level of education (Table 2).

Table 2. Variants of learning approaches that are proven to develop SPS

\begin{tabular}{|c|c|c|c|c|c|c|c|}
\hline \multirow{2}{*}{ No } & \multirow{2}{*}{ Varians } & \multicolumn{4}{|c|}{ Frequency } & & \multirow{2}{*}{$\begin{array}{l}\text { Proportion } \\
(\%)\end{array}$} \\
\hline & & ES & JHS & SHS & $\mathrm{HE}$ & & \\
\hline 1 & Inquiry & 1 & 1 & 1 & 0 & 3 & 18.75 \\
\hline 2 & Saintifik & 4 & 2 & 1 & 0 & 7 & 43.75 \\
\hline 3 & Contextual & 1 & 1 & 0 & 0 & 2 & 12.50 \\
\hline 4 & Guided inquiry & 0 & 0 & 1 & 0 & 1 & 6.25 \\
\hline 5 & Interactive demonstration & 0 & 0 & 1 & 0 & 1 & 6.25 \\
\hline 6 & Brain based learning & 0 & 0 & 1 & 0 & 1 & 6.25 \\
\hline 7 & SAVIR & 0 & 0 & 1 & 0 & 1 & 6.25 \\
\hline
\end{tabular}

Based on Table 2, there are two approaches that have been proven to develop students' KPS at the primary and secondary education levels. These two approaches are inquiry and scientific. From the implementation aspect, the scientific approach has a larger proportion (43.75) compared to the inquiry approach. In junior secondary education, scientific approaches can be combined with learning models. Inquiry and guided inquiry approaches can also be combined with learning models, but at the high school level.

\section{3) Learning model}

Among all types of learning facilities, the learning model is the facility that has the most variants. In total there are 35 variants of the learning model. Of these, there is 1 variant that is proven to be effective in developing SPS for students and students, 5 variants are proven to be effective in primary and secondary education, 34 variants are proven to be effective in secondary education and higher education, and 2 variants are proven to be effective only in secondary education. As for the other variants so far only proven effective in certain education. More complete information is presented in Table 3.

Table 3 shows that the inquiry learning model is mostly implemented in order to develop students' KPS. Total reports in the form of scientific articles that have proven the efficacy of this model are 62 documents, with a proportion of $31.47 \%$ compared to other learning models. In second place there are three learning models, namely PBL, PjBL and inquiry with 19 documents published $(9.64 \%)$. Then sequentially there are learning cycle, discovery learning, cooperative, and POE learning models which are in the third, fourth, fifth, and sixth ranks. The number of articles is $15,11,8$, and 7 documents. The other learning models still have a limited number of tests. The range of the number of articles is 1 to 3 documents. 
Table 3. Variants of learning models that are proven to be able to develop KPS

\begin{tabular}{|c|c|c|c|c|c|c|c|}
\hline \multirow{2}{*}{ No } & \multirow{2}{*}{ Varians } & \multicolumn{4}{|c|}{ Frequency } & & \multirow{2}{*}{$\begin{array}{c}\text { Proportion } \\
(\%)\end{array}$} \\
\hline & & $\mathrm{ES}$ & JHS & SHS & $\mathrm{HE}$ & & \\
\hline 1 & Guided inquiry & 8 & 17 & 37 & 0 & 62 & 31.47 \\
\hline 2 & PBL & 4 & 0 & 12 & 3 & 19 & 9.64 \\
\hline 3 & Learning cycle & 3 & 4 & 8 & 0 & 15 & 7.61 \\
\hline 4 & Direct instruction & 1 & 0 & 0 & 0 & 1 & 0.51 \\
\hline 5 & POE & 2 & 0 & 4 & 1 & 7 & 3.55 \\
\hline 6 & PjBL & 4 & 3 & 10 & 2 & 19 & 9.64 \\
\hline 7 & Inquiry & 2 & 10 & 7 & 0 & 19 & 9.64 \\
\hline 8 & Discovery learning & 1 & 9 & 1 & 0 & 11 & 5.58 \\
\hline 9 & Preser-X & 1 & 0 & 1 & 0 & 1 & 0.51 \\
\hline 10 & Cooperatif & 1 & 0 & 7 & 0 & 8 & 4.06 \\
\hline 11 & POGIL & 1 & 1 & 1 & 0 & 1 & 1.02 \\
\hline 12 & STEM & 1 & 0 & 1 & 0 & 1 & 0.51 \\
\hline 13 & Example non-example & 1 & 0 & 1 & 0 & 1 & 0.51 \\
\hline 14 & CTL & 1 & 0 & 1 & 0 & 1 & 0.51 \\
\hline 15 & Quantun learning & 0 & 1 & 0 & 0 & 1 & 0.51 \\
\hline 16 & Experiental learning & 0 & 2 & 0 & 0 & 2 & 1.02 \\
\hline 17 & ADDIE & 0 & 1 & 0 & 0 & 1 & 0.51 \\
\hline 18 & IDL & 0 & 1 & 1 & 0 & 2 & 1.02 \\
\hline 19 & Pair checks & 0 & 1 & 0 & 0 & 1 & 0.51 \\
\hline 20 & CLiS & 0 & 1 & 1 & 1 & 3 & 1.52 \\
\hline 21 & Guided discovery & 0 & 1 & 2 & 0 & 3 & 1.52 \\
\hline 22 & Context based learning & 0 & 0 & 1 & 0 & 1 & 0.51 \\
\hline 23 & Problem solving & 0 & 0 & 1 & 0 & 1 & 0.51 \\
\hline 24 & ICARE & 0 & 0 & 1 & 0 & 1 & 0.51 \\
\hline 25 & REACT & 0 & 0 & 3 & 0 & 3 & 1.52 \\
\hline 26 & Generatif & 0 & 0 & 2 & 0 & 2 & 1.02 \\
\hline 27 & Direct instruction & 0 & 0 & 2 & 0 & 2 & 1.02 \\
\hline 28 & SETS & 0 & 0 & 1 & 0 & 1 & 0.51 \\
\hline 29 & Problem posing & 0 & 0 & 1 & 0 & 1 & 0.51 \\
\hline 30 & Creative problem solving & 0 & 0 & 1 & 0 & 1 & 0.51 \\
\hline 31 & FERA & 0 & 0 & 1 & 0 & 1 & 0.51 \\
\hline 32 & Practice-based learning & 0 & 0 & 1 & 0 & 1 & 0.51 \\
\hline 33 & Problem-based instruction & 0 & 0 & 0 & 1 & 1 & 0.51 \\
\hline 34 & CCDSR & 0 & 0 & 0 & 1 & 1 & 0.51 \\
\hline
\end{tabular}

Where PBL: Problem-based Learning; POE: Predict, Obserb, Explain; PjBL: Project-based Learning; POGIL: Process Oriented Guided Inquiry Learning; STEM: Science Technology Enginering Mathematic; CTL: Contextual Teaching And Learning; ADDIE: Analysis Design Developt Implement Evaluate; IDL: Inquiry Discovery Learning; CliS: Children Learning in Science; ICARE: Introduction-Connect-Apply-Reflect-Extend; SETS: Science Environment Technology Society; FERA: Focus Explore Refflect Apply; CCDSR: Condition, Construction, Development, Simulation, Reflection.

\section{4) Learning method}

This type of learning facility consists of 11 variants. The eleven variants that have been proven to be able to develop SPS are the methods: (1) experiment, (2) project, (3) pictorial riddle, (4) practicum, (5) field trip, (6) outdoor learning, (7) mind mapping , (8) learning management system (LMS), (9) group work, (10) discovery, and (11) spot capturing. The number and distribution of implementation at various levels of education are presented in Table 4.

Table 4. Variants of learning methods that are proven to be able to develop KPS

\begin{tabular}{clcccccc}
\hline \multirow{2}{*}{ No } & \multirow{2}{*}{ Nama Varian } & \multicolumn{4}{c}{ Frequency } & \multicolumn{2}{c}{$\begin{array}{c}\text { Proportion } \\
(\%)\end{array}$} \\
\cline { 2 - 6 } & & ES & JHS & SHS & Col. & & 30 \\
2 & Experiment & 2 & 1 & 4 & 2 & 9 & 3.33 \\
\hline
\end{tabular}




\begin{tabular}{clllllcc}
\hline 3 & Pictorial riddle & 0 & 1 & 0 & 0 & 1 & 3.33 \\
4 & Praktikum & 0 & 1 & 9 & 2 & 12 & 40 \\
5 & Field trip & 0 & 1 & 0 & 0 & 1 & 3.33 \\
6 & Outdor Learning & 0 & 1 & 0 & 0 & 1 & 3.33 \\
7 & Mind mapping & 0 & 1 & 0 & 0 & 1 & 3.33 \\
8 & LMS & 0 & 0 & 1 & 0 & 1 & 3.33 \\
9 & Karya kelompok & 0 & 0 & 1 & 0 & 1 & 3.33 \\
10 & Discovery & 0 & 0 & 1 & 0 & 1 & 3.33 \\
11 & Spot Capturing & 0 & 0 & 0 & 1 & 1 & 3.33 \\
\hline
\end{tabular}

Table 3 informs that the experimental learning method has been convincingly proven through the research process to develop the KPS of students in primary education, secondary education, and students in higher education. The number of articles published and showing the effectiveness of this method is 9 documents with a proportion of $30 \%$ compared to other learning methods. The practicum learning method, although only proven in secondary education and higher education, has more published articles, namely 12 documents (40\%). The other learning methods still have limited evidence, both in the number of articles and the level of education.

\section{5) Learning media}

There are 28 variants of learning media that have been proven to be effective in developing KPS for students and students in Indonesia. This number is in second place after learning media. In its implementation, some of these media are combined with other learning facilities. For example, in the learning process in basic education, modules and electronic media are combined with the PjBL model, audiovisual media is combined with a guided inquiry model, LKS is combined with the Preser-X model, and performance assessment is combined with a cooperative group investigation model. More complete information related to variants of learning media is presented in Table 5 below.

Table 5. Variants of learning media that are proven to be able to develop SPS

\begin{tabular}{clcccccc}
\hline \multirow{2}{*}{ No } & \multirow{2}{*}{ Varians } & \multicolumn{2}{c}{ Frequency } & \multicolumn{2}{c}{ Proportion } \\
\cline { 2 - 5 } & & ES & JHS & SHS & Col. & & 26.53 \\
\hline 1 & Modul & 1 & 7 & 14 & 4 & 26 & 3.06 \\
2 & Media Audiovisual & 1 & 0 & 0 & 2 & 3 & 30.61 \\
3 & Lembar kerja & 2 & 8 & 15 & 5 & 30 & 1.02 \\
4 & Asessmen Kinerja & 1 & 0 & 0 & 0 & 1 & 1.02 \\
5 & Electronic media & 1 & 0 & 0 & 0 & 1 & 1.02 \\
6 & Interactive multimedia & 1 & 0 & 0 & 0 & 1 & 1.02 \\
7 & KIT IPA & 1 & 0 & 0 & 0 & 1 & 6.12 \\
8 & Potensi lokal & 0 & 3 & 0 & 3 & 6 & 3.06 \\
9 & Bahan ajar & 0 & 1 & 1 & 1 & 3 & 1.02 \\
10 & Rumpon & 0 & 1 & 0 & 0 & 1 & 1.02 \\
11 & Media visual & 0 & 1 & 0 & 0 & 1 & 2.04 \\
12 & PeHET & 0 & 1 & 1 & 0 & 1 & 1.02 \\
13 & SCM & 0 & 1 & 0 & 0 & 1 & 1.02 \\
14 & Lingkungan & 0 & 0 & 1 & 0 & 1 & 1.02 \\
15 & Diagram Vee & 0 & 0 & 1 & 0 & 1 & 2.04 \\
16 & Video & 0 & 0 & 1 & 1 & 2 & 1.02 \\
17 & Multimedia & 0 & 0 & 1 & 0 & 1 & 1.02 \\
18 & Mind Map & 0 & 0 & 1 & 0 & 1 & 1.02 \\
19 & Peta konsep & 0 & 0 & 1 & 0 & 1 & 1.02 \\
20 & Kartu Pintar Fisika & 0 & 0 & 1 & 0 & 1 & 1.02 \\
21 & SPQ & 0 & 0 & 1 & 0 & 1 & 1.02 \\
22 & Performance Assesment & 0 & 0 & 1 & 2 & 3 & 3.06 \\
23 & Virtual Laboratory & 0 & 0 & 0 & 1 & 1.02 \\
24 & KIT Microscale & 0 & 0 & 02
\end{tabular}

Jurnal Kependidikan Vol. 7, No. 4 (December 2021) 
25 Petunjuk praktikum

26 Contex-Rich Problem

27 Textbooks

28 The bomb calorimeter

$\begin{array}{lll}0 & 0 & 0 \\ 0 & 0 & 0 \\ 0 & 0 & 0 \\ 0 & 0 & 0\end{array}$

4.08

1.02

1.02

1.02

Where SCM: Scientific Concept Map; SPQ: Scaffolding Prompting Questioning.

Based on Table 5, modules and worksheets are the most widely used variants of learning media to develop PPP in Indonesia. Both have been proven at all levels of education, from basic education to higher education. Respectively, the number of articles identified regarding their effectiveness were 26 and 30 documents. The proportions of both are $26.53 \%$ and $30.61 \%$ compared to the other variants. The other variants of learning media still have a limited number of implementations. The range of the number of uses is $1-6$ refers to the number of article documents that have been published through journals or seminar proceedings.

\section{6) Learning aids}

Learning aids are a type of learning facility that has the least variance. From a total of 351 article documents, there are only 5 variants that have been proven to be able to develop student and student KPS. The five variants are (1) Musschenbroek, (2) business and energy teaching aids, (3) versatile optical KIT, (4) viscosity tool, and (5) Newton's Law II practical tool. Its implementation is still very limited because the publication articles are 1 document each, and it is only proven at one level of education, namely in secondary education (Table 6). In its implementation, business and energy teaching aids are combined with the inquiry discovery learning model.

Table 6. Variants of teaching aids that are proven to be able to develop SPS

\begin{tabular}{clcccccc}
\hline \multirow{2}{*}{ No } & \multirow{2}{*}{ Varians } & \multicolumn{4}{c}{ Frequency } & \multicolumn{2}{c}{ Proportion } \\
\cline { 2 - 5 } & & ES & JHS & SHS & Col. & & $(\%)$ \\
\hline 1 & Musschenbroek & 0 & 1 & 0 & 0 & 1 & 20 \\
2 & Alat peraga UN & 0 & 1 & 0 & 0 & 1 & 20 \\
3 & KIT Optik Serbaguna & 0 & 1 & 0 & 0 & 1 & 20 \\
4 & Alat viskositas & 0 & 0 & 1 & 0 & 1 & 20 \\
5 & Alat praktikum HN-II & 0 & 0 & 1 & 0 & 1 & 20 \\
\hline
\end{tabular}

Where UN: usaha dan energi; HN-II: hukum Newton II

\section{7) Learning tools}

Naming variants for this type of learning facility is based on the basis, orientation or the like. Based on these criteria, there are 14 variants of learning tools that have been proven through the research process to develop SPS for students in Indonesia (Table 7).

Table 7. Variants of learning aids that are proven to be able to develop SPS

\begin{tabular}{clcccccc}
\hline N & \multirow{2}{*}{ Nama Varian } & \multicolumn{4}{c}{ Frequency } & \multicolumn{2}{c}{ Proportion } \\
\cline { 2 - 5 } & ES & JHS & SHS & Col. & & $(\%)$ \\
\hline 1 & Inkuiri Terbimbing & 1 & 0 & 3 & 0 & 4 & 33.79 \\
2 & Non-basis & 1 & 0 & 0 & 0 & 1 & 3.45 \\
3 & Guided Inquiry & 0 & 9 & 0 & 0 & 9 & 31.035 \\
4 & Berbasis Inkuiri & 0 & 4 & 0 & 0 & 4 & 13.795 \\
5 & Pendekatan ilmiah & 0 & 1 & 0 & 0 & 1 & 3.45 \\
6 & Berbasis PBL + TPS & 0 & 0 & 2 & 0 & 2 & 6.89 \\
7 & Model POE & 0 & 0 & 1 & 0 & 1 & 3.45 \\
8 & Simulasi PhET & 0 & 0 & 1 & 0 & 1 & 3.45 \\
9 & Lingkungan sekitar & 0 & 0 & 1 & 0 & 1 & 3.45 \\
10 & Model IDL & 0 & 0 & 1 & 0 & 1 & 3.45 \\
11 & Berbasis desain & 0 & 0 & 1 & 0 & 1 & 3.45 \\
12 & Kegiatan ecotourism & 0 & 0 & 1 & 0 & 1 & 3.45 \\
13 & Susan Loucks Horsley & 0 & 0 & 1 & 0 & 1 & 3.45 \\
14 & Model PjBL & 0 & 0 & 1 & 0 & 1 & 3.45 \\
\hline
\end{tabular}


Based on the review data that has been presented previously, we recommend a number of learning facilities that can be used by teachers and lecturers in developing KPS. In total there are 7 variants of recommended learning facilities. This recommendation refers to the results of article reviews. The criteria are five variants that have the highest number of publications. The 7 recommended variants come from two types of learning facilities, namely models and learning media. Five variants of the learning model, and two variants of the learning media. Two variants of this learning media are modules and worksheets. Five variants of the learning model include guided inquiry, PBL, learning cycle, PjBL, and inquiry.

Guided inquiry is a variant of the type of learning model that has the highest number of published articles (62 documents). The number of published articles is distributed at all levels of education, from basic education, junior secondary education, senior secondary education to higher education. This proves that the guided inquiry learning model has been proven to be able to develop students' and students' SPS with various characteristics or high heterogeneity. These characteristics such as the level of cognitive development, learning style and motivation, and various other characteristics that affect the learning experience and achievement of learning objectives. The advantages of this learning model as expressed by Marwan et al. (2021) is to create learning that is fun, active, creative and fun by guiding students and students to find a number of scientific knowledge for themselves.

Based on the fact that in the process students and students discover a number of scientific knowledge for themselves, it shows that guided inquiry includes student center learning. From the syntax, student center learning is also observed in the PBL, learning cycle, PjBL, and inquiry learning models (Adnan et al., 2021; Anazifa \& Djukri, 2017; Salyani et al., 2020). Like the guided inquiry learning model, this learning model has also been proven to be able to develop SPS at various levels of education in Indonesia. The number of published articles ranging from 15 to 19 documents also shows that the learning model can provide meaningful learning experiences for various characteristics of students and students. In order to increase the knowledge base, researchers can try the guided inquiry model, learning cycle and inquiry for students in higher education, and the PBL model in junior secondary education. The PjBL model can be tested at all levels of education to obtain more data regarding its effect on PPP development.

In addition to the learning model, the researcher also recommends the implementation of learning media to develop SPS. These learning media are modules and worksheets. The large number of published articles that have been tested at all levels of education in Indonesia proves that both learning media are effective on students and students with various characteristics. The results of the review show that the module in its implementation can be combined with the guided inquiry learning model, or PjBL. The worksheet media can be combined with the Preser-X learning model, discovery learning, or inquiry. Other modules and worksheets are developed based on an approach or learning model that has been proven to be able to develop student and student SPS. Media developed based on guided inquiry models are even valid for use during the pandemic (Munzil \& Rochmawati, 2021).

Apart from the 7 variants of the recommended learning facilities, other variants can also be tested because they have been proven to be effective in developing students' SPS. This is important to enrich the repertoire of knowledge, and as a real effort to facilitate heterogeneous students and students according to their characteristics. Factors that need to be considered include (1) readiness in implementing, (2) the suitability of learning facilities and the characteristics of students or students, and (3) the suitability of learning facilities and teaching topics/materials. If these factors are met, then the SPS can be developed for both 
students (Anjarwani et al., 2019; Maharani et al., 2020; Tyas et al., 2020) as well as university students (Patresia et al., 2020) . On a broader scale, this can fulfill some aspects of the national education goals based on Law Number 20 of 2003 concerning the National Education System.

\section{Conclusion}

Based on the results of this literature review, it can be concluded that (1) there are 7 types of learning facilities that can develop students' and students' KPS in Indonesia, namely devices, strategies, approaches, models, methods, media, and teaching aids; (2) a total of 106 variants of the 7 types of learning facilities; and (3) from a number of these variants, some of which are recommended for use by educators in the learning process. The variants are guided inquiry learning model, learning cycle, PBL, PjBL and inquiry, as well as learning media modules and worksheets.

\section{Recommendation}

Recommendation that can be submitted based on the results of this literature review research include: (1) educators can use various types and variants of learning facilities that have been empirically proven to be able to develop student and student KPS, (2) by considering the number of publications, educators can prioritizing the use of the recommended 7 variants of learning facilities, (3) it is necessary to consider the heterogeneity aspect of the students or students who are the subject of learning, and (4) the teacher readiness factor and the availability of facilities and infrastructure also need to be considered in implementing a particular learning facility.

\section{References}

Adnan, G., Zulfikar, T., Armia, M. S., Gade, S., \& Walidin, W. (2021). Impacts of inquiry learning model on students' cognitive and critical thinking ability. Cypriot Journal of Educational Sciences, 16(3), 1290-1299. https://doi.org/10.18844/cjes.v16i3.5851

Amalia, N., \& Kurniawati, F. (2021). Studi literatur: Peran guru pendidikan khusus di sekolah inklusi. Jurnal Kependidikan: Jurnal Hasil Penelitian Dan Kajian Kepustakaan Di Bidang Pendidikan, Pengajaran Dan Pembelajaran, 7(2), 361-371. https://doi.org/10.33394/jk.v7i2.3730

Anazifa, R. D., \& Djukri. (2017). Project-based learning and problem-based learning: Are they effective to improve student's thinking skills? Jurnal Pendidikan IPA Indonesia, 6(2), 346-355. https://doi.org/10.15294/jpii.v6i2.11100

Anjarwani, R., Doyin, M., \& Indiatmoko, B. (2019). Guided inquiry learning with outdoor activities setting to improve critical thinking ability and science process skills of elementary school students. Journal of Primary Education, 9(2), 129-135. https://doi.org/10.15294/jpe.v9i2.36178

Badria, I. L., Ibrohim, I., \& Suhadi, S. (2021). The implementation of problem-based learning model with the local potential resources in Kebundadap Timur-Sumenep district to improve science process skills and environmental attitudes of SMA students. AIP Conference Proceedings, 2330, 030019-1-030019-6. https://doi.org/10.1063/5.0043412

Can, B., Yildiz-Demirtas, V., \& Altun, E. (2017). The effect of project- based science education programme on scientific process skills and conceptions of Kindergarten students. Journal of Baltic Science Education, 16(3), 395-413. 
Deta, U. A., Prakoso, I., Agustina, P. Z. R., Fadillah, R. N., Lestari, N. A., Yantidewi, M., Admoko, S., Zainuddin, A., Nurlailiyah, A., \& Prahani, B. K. (2020). Science process skills profile of non-science undergraduate student in Universitas Negeri Surabaya. Journal of Physics: Conf. Series. https://doi.org/10.1088/1742-6596/1491/1/012067

Giatman, M., Siswati, S., \& Basri, I. Y. (2020). Online learning quality control in the pandemic Covid-19 era in Indonesia. Journal of Nonformal Education, 6(2), 168-175. https://doi.org/10.15294/jne.v6i2.25594

Hidayati, D., \& Saputra, W. A. (2020). Implementation of online learning during the Covid19 epidemic in Indonesia: Assessment of higher education students' use and implementation of online learning technology. Universal Journal of Educational Research, 8(10), 4514-4519. https://doi.org/10.13189/ujer.2020.081019

Huang, Y. C. (2021). Comparison and contrast of Piaget and Vygotsky's Theories. 7th International Conference on Humanities and Social Science Research (ICHSSR 2021), 28-32.

Julianto, Wasis, \& Agustini, R. (2018). Profil sikap terhadap sains, keterampilan proses sains, dan kreativitas mahasiswa Jurusan PGSD FIP UNESA di Mata Kuliah Konsep Dasar IPA. Seminar Nasional Pendidikan, 197-202.

Maharani, R. J. P., Taufik, M., Ayub, S., \& Rokhmat, J. (2020). Pengaruh model pembelajaran inkuiri dengan bantuan media tiga dimensi terhadap keterampilan proses sains dan hasil belajar fisika peserta didik. Jurnal Penelitian Pendidikan IPA, 6(1), 113. https://doi.org/10.29303/jppipa.v6i1.326

Marwan, A., Hasruddin, H., \& Yusnadi, Y. (2021). The Effect of guided inquiry learning model on process skills science and students' higher-level thinking skills on heat and transfer themes of class V SD Negeri 104260 Melati. Budapest International Research and Critics in Linguistics and Education (BirLE) Journal, 4(2), 901-910. https://doi.org/10.33258/birle.v4i2.1931

Mirawati, I., Mahameruaji, J. N., \& Trulline, P. (2020). Indonesian student's perception of online learning activities in the time of pandemic. European Journal of Molecular and Clinical Medicine, 7(1), 3645-3652.

Munzil, M., \& Rochmawati, S. (2021). Development of e-learning teaching materials based on guided inquiry models equipped with augmented reality on hydrocarbon topics as teaching materials for COVID-19 pandemic. AIP Conference Proceedings, 2330, 020025-1-020025-020027. https://doi.org/10.1063/5.0043238

Nurulwati, Herliana, F., Elisa, \& Musdar. (2021). The effectiveness of project-based learning to increase science process skills in static fluids topic. AIP Conference Proceedings, 2320, 020037-1-020037-5. https://doi.org/10.1063/5.0037628

Patresia, I., Silitonga, M., \& Ginting, A. (2020). Developing biology student s ' worksheet based on STEAM to empower science process skills. JPBI (Jurnal Pendidikan Biologi Indonesia), 6(1), 147-156. https://doi.org/10.2229/jpbi.v6i1. 10225

Prahani, B. K., Deta, U. A., Lestari, N. A., Yantidewi, M., Jauhariyah, M. N. R., Kelelufna, V. P., Siswanto, J., Misbah, M., Mahtari, S., \& Suyidno. (2021). A profile of senior high school students' science process skills on heat material. Journal of Physics: Conference Series, 1760, 1-5. https://doi.org/10.1088/1742-6596/1760/1/012010

Prayitno, B. A., Corebima, D., Susilo, H., Zubaidah, S., \& Ramli, M. (2015). Closing the science process skills GAP between students with high and low level academic achievement. Journal of Baltic Science Education, 16(2), 266-277. 
Rahayu, A. H., \& Anggraeni, P. (2017). Analisis profil keterampilan proses sains siswa Sekolah Dasar di Kabupaten Sumedang. Pesona Dasar (Jurnal Pendidikan Dasar Dan Humaniora), 5(2), 22-33. https://doi.org/10.24815/pear.v7i2.14753

Rahman, A., Wahyuni, I., \& Rifqiawati, I. (2017). Profil keterampilan proses sains dan sikap ilmiah siswa di SMP Satu Atap Pulau Tunda. School Education Journal, 7(1), 1-7. https://doi.org/10.24114/sejpgsd.v7i1.6827

Salyani, R., Nurmaliah, C., \& Mahidin, M. (2020). Application of the 5E learning cycle model to overcome misconception and increase student learning activities in learning chemical bonding. Journal of Physics: Conference Series, 1460, 1-7. https://doi.org/10.1088/1742-6596/1460/1/012102

Sari, P. M., \& Zulfadewina. (2018). Profile of science process skill mastery from pre-service elementary school teacher. Jurnal Inovasi Pendidikan Dasar, 3(2), 65-72.

Schleicher, A. (2019). PISA 2018: Insights and Interpretations. EOCD.

Tyas, R. A., Wilujeng, I., \& Suyanta, S. (2020). Pengaruh pembelajaran IPA berbasis discovery learning terintegrasi jajanan lokal daerah terhadap keterampilan proses sains. Jurnal Inovasi Pendidikan IPA, 6(1), 114-125. https://doi.org/10.21831/jipi.v6i1.28459 